\title{
T-Cell Mediation of Pregnancy Analgesia Affecting Chronic Pain in Mice
}

\author{
Sarah F. Rosen, ${ }^{1}$ Boram Ham, ${ }^{1}$ CShannon Drouin, ${ }^{1}$ Nadia Boachie, ${ }^{1}$ Anne-Julie Chabot-Dore,${ }^{2}$ Jean-Sebastien Austin, ${ }^{1}$ \\ Luda Diatchenko, ${ }^{2}$ and Jeffrey S. Mogil ${ }^{1}$ \\ ${ }^{1}$ Department of Psychology and Alan Edwards Centre for Research on Pain, McGill University, Montreal, Quebec H3A 1B1, Canada, and 2Department of \\ Anesthesia, Faculty of Dentistry and Alan Edwards Centre for Research on Pain, McGill University, Montreal, Quebec H3A 0G1, Canada
}

It has been reported consistently that many female chronic pain sufferers have an attenuation of symptoms during pregnancy. Rats display increased pain tolerance during pregnancy due to an increase in opioid receptors in the spinal cord. Past studies did not consider the role of non-neuronal cells, which are now known to play an important role in chronic pain processing. Using an inflammatory (complete Freund's adjuvant) or neuropathic (spared nerve injury) model of persistent pain, we observed that young adult female mice in early pregnancy switch from a microglia-independent to a microglia-dependent pain hypersensitivity mechanism. During late pregnancy, female mice show no evidence of chronic pain whatsoever. This pregnancy-related analgesia is reversible by intrathecal administration of naloxone, suggesting an opioid-mediated mechanism; pharmacological and genetic data suggest the importance of $\delta$-opioid receptors. We also observe that T-cell-deficient (nude and Rag1-null mutant) pregnant mice do not exhibit pregnancy analgesia, which can be rescued with the adoptive transfer of $\mathrm{CD} 4{ }^{+}$or $\mathrm{CD} 8{ }^{+} \mathrm{T}$ cells from late-pregnant wild-type mice. These results suggest that $\mathrm{T}$ cells are a mediator of the opioid analgesia exhibited during pregnancy.

Key words: adaptive immunity; delta-opioid; pain; pregnancy; T cells

\section{Significance Statement}

Chronic pain symptoms often subside during pregnancy. This pregnancy-related analgesia has been demonstrated for acute pain in rats. Here, we show that pregnancy analgesia can produce a complete cessation of chronic pain behaviors in mice. We show that the phenomenon is dependent on pregnancy hormones (estrogen and progesterone), $\delta$-opioid receptors, and T cells of the adaptive immune system. These findings add to the recent but growing evidence of sex-specific T-cell involvement in chronic pain processing.

\section{Introduction}

Although pregnancy is a risk factor for the development of a number of pain states (Block and Biller, 2014; Casagrande et al., 2015), it is also well known that many women with preexisting chronic pain states experience an attenuation of symptoms during pregnancy (LeResche et al., 2005; Melhado et al., 2007; Ostensen and Villiger, 2007; Block and Biller, 2014). Studies in the

Received July 20, 2017; revised Aug. 28, 2017; accepted Aug. 29, 2017.

Author contributions:S.F.R. and J.S.M. designed research;S.F.R., B.H., S.D., N.B., A.-J.C.-D., and J.-S.A. performed research; L.D. contributed unpublished reagents/analytic tools; S.F.R. and J.S.M. analyzed data; S.F.R., L.D., and J.S.M. wrote the paper.

This work was supported by the Canadian Institutes for Health Research (Operating Grant MOP-123307) and Brain Canada (Multi-Investigator Research Initiative Award). S.F.R. was supported by a Doctoral Studentship in Pain Research from the Louise and Alan Edwards Foundation. The remaining authors declare no competing financial interests.

Correspondence should be addressed to Jeffrey S. Mogil, Ph.D., Dept. of Psychology, McGill University, 1205 Dr. Penfield Ave., Montreal, QC H3A 1B1 Canada. E-mail: jeffrey.mogil@mcgill.ca.

DOI:10.1523/JNEUROSCI.2053-17.2017

Copyright $\odot 2017$ the authors $\quad 0270-6474 / 17 / 379819-09 \$ 15.00 / 0$ rat have shown opioid-receptor-mediated increases in acute pain tolerance during pregnancy that peaks at parturition (Gintzler, 1980) and similar changes in acute pain sensitivity have been demonstrated in pregnant women (Rust et al., 1985; Cogan and Spinnato, 1986; but see Goolkasian and Rimer, 1984; Dunbar et al., 1988). Gintzler and colleagues, in a series of studies in the rat, have established the importance of pregnancy-relevant gonadal hormones and spinal cord opioid receptors in producing pregnancy analgesia (Gintzler and Liu, 2001). Iwasaki et al. (1991) also observed naloxone-reversible analgesia in the late stages of pregnancy in the colorectal distension, tail-flick, and hot-plate tests. Jayaram et al. (1995, 1997), working in mice, provided evidence for enkephalin mediation of pregnancy analgesia with the observation that the enkephalinase inhibitors SCH 32615 and RB 101 enhance the phenomenon. These studies are limited in their clinical relevance in that they used only acute noxious stimuli. Very recently, however, the reduction of mechanical pain hypersensitivity (allodynia) produced by a chronic constriction injury in late pregnancy in the rat was reported (Onodera et al., 2017). 
The bulk of the pregnancy analgesia literature was compiled before it was widely recognized that neurons are not the only cell type processing pain; cells of the immune system such as microglia, macrophages, and T cells are now known to perform important signaling roles (Beggs and Salter, 2010; Grace et al., 2014; McMahon et al., 2015; Ji et al., 2016). We recently demonstrated that females are likely using adaptive immune cells, T cells, to produce pain hypersensitivity after injury, whereas males use microglia to achieve the same ends (Sorge et al., 2015). A possible underlying explanation of this sex difference is that females have a stronger adaptive immune system and more circulating $\mathrm{T}$ cells than males (Scotland et al., 2011). During pregnancy, due to changes in sex hormone levels and for the purposes of protection of the fetus, females mount a dampened adaptive immune response (Saito et al., 2010). We wished to investigate the implications for the apparent sex dependence of spinal cord neuroimmune processing of pain in pregnant mice.

Here, we observed that female mice (of two different strains) with a neuropathic or inflammatory injury in the early stages of pregnancy switched from a microglia-independent system of pain signaling to a microglia-dependent system. In late pregnancy, females no longer exhibited any signs of chronic pain whatsoever. We also show that, in the mouse, as in the rat, pregnancy analgesia appears to be mediated by gonadal hormones and opioid receptors, specifically the $\delta$-opioid receptor. Completely novel is the demonstration that this phenomenon is utterly dependent on $\mathrm{T}$ cells.

\section{Materials and Methods}

Experimental design and statistical analysis. Experiments were performed by investigators blinded to drug or hormone group and mice were assigned to drug groups randomly within cages. Blinding to sex/pregnancy status and genotype was obviously not possible. Most behavioral experiments involved the evaluation of the effects of injuries, drugs, and/or hormones on pain behaviors and were analyzed with repeated-measures ANOVAs as appropriate (Systat version 13). Post hoc comparisons were made using the post hoc test for repeated measures with Sidak correction. An $\alpha$ criterion of 0.05 was adopted in all experiments. Because these studies were exploratory in nature (Kimmelman et al., 2014) and the phenomenon being studied was entirely novel in the mouse, formal power analyses were not appropriate. Sample sizes were instead based on standard practices in the preclinical pain field (Mogil et al., 2006) and in some cases were dictated by breeding success. In five cases, individual data points were removed from the analysis after being identified as statistical outliers (Studentized residuals $>3$ ).

Subjects. Experiments were performed on naive, adult (7-12 weeks of age) male and female mice. Outbred CD-1 (Crl:ICR) and nude (Crl:CD1Foxn $1^{\mathrm{nu}}$ ) mice were bred in-house from breeders obtained from Charles River Laboratories. C57BL/6J mice were purchased from The Jackson Laboratory and Rag1 ${ }^{-1-}\left(\mathrm{C} 57 \mathrm{BL} / 6-\operatorname{Rag} 1^{\mathrm{tm} 1 \mathrm{Mom}}\right)$ mice were bred inhouse from breeders obtained from M. Saleh (McGill University). Null mutant mice lacking expression of the Oprd1 ( $\delta$-opioid receptor) gene $\left(O p r d 1^{-1-} ;\right.$ C57BL/6-Oprd1 $\left.{ }^{\text {tm1Kff }}\right)$ were bred in-house from breeders obtained from L. Diatchenko (McGill University). Mice were housed with their same-sex littermates (2-4 animals per cage) in standard shoebox cages, maintained in a temperature controlled $\left(20 \pm 1^{\circ} \mathrm{C}\right)$ environment (12:12 h light/dark cycle; lights on at 07:00 h), and received food (Harlan Teklad 8604) and water ad libitum. Early-pregnant females were defined as being $5-7$ d into a $20 \pm 1$ d gestation period (i.e., $\approx \mathrm{P}-14$; with $\mathrm{P}-20$ being defined as the day after discovery of a vaginal plug), and late-pregnant females were defined as $16-21 \mathrm{~d}$ into gestation (i.e., $\approx \mathrm{P}-2$ ). Postweaning females were defined as primiparous mice $7-8 \mathrm{~d}$ after pup weaning at $20-21 \mathrm{~d}$ postparturition (i.e., $\approx 28 \mathrm{~d}$ after birth; P 28).

Gonadectomy and hormone replacement. Ovariectomies occurred under isoflurane/oxygen anesthesia via the dorsal approach $7 \mathrm{~d}$ before retesting. Hormonal replacement was achieved via subcutaneous implantation of osmotic minipumps (Alzet model 2002), releasing one of the following: (1) vehicle $(0.5 \mu \mathrm{l} / \mathrm{h} / \mathrm{d}),(2) 17 \beta$-estradiol $(0.1 \mathrm{mg} / \mathrm{kg} / \mathrm{d}$; $0.042 \mathrm{mg}$ total $),(3)$ progesterone sulfate $(0.25 \mathrm{mg} / \mathrm{kg} / \mathrm{d} ; 0.105 \mathrm{mg}$ total $)$, or (4) hormone-stimulated pregnancy $(0.1 \mathrm{mg} / \mathrm{kg} / \mathrm{d}$ estradiol +0.25 $\mathrm{mg} / \mathrm{kg} / \mathrm{d}$ progesterone) (Dawson-Basoa and Gintzler, 1993). Pain sensitivity was assessed before and $14 \mathrm{~d}$ after pump implantation. Therefore, in all experiments, 3 weeks elapsed between ovariectomy and final behavioral testing.

Inflammatory assays. After testing for baseline mechanical sensitivity on two separate occasions (see below), mice were injected with complete Freund's adjuvant (CFA; $50 \%$, in a $20 \mu$ linjection volume) into the left hindpaw. Mice were retested 3 d later to confirm the presence of mechanical allodynia and then (in many but not all studies) at various time points after drug injection up to $120 \mathrm{~min}$ after drug. In one study, after baseline mechanical testing, mice were injected with lipopolysaccharide (LPS; Escherichia coli serotype 0111:B4; Sigma-Aldrich) intrathecally $(0.1 \mu \mathrm{g} ; 5 \mu \mathrm{l}$ injection volume) (Hylden and Wilcox, 1980) and retested $1,2,4,6$, and $24 \mathrm{~h}$ later.

In two studies, mice were tested before and after CFA for noxious thermal sensitivity or spontaneous pain behavior (see below).

Neuropathic assay. After testing for baseline mechanical sensitivity on two separate occasions, mice were subjected to a unilateral spared nerve injury (SNI) surgery (Decosterd and Woolf, 2000) as adapted for mice (Shields et al., 2003). We spared the sural territory, so von Frey stimuli were aimed at the lateral aspect of the hindpaw. Mice were retested for mechanical allodynia on postoperative day 7 (the earliest time point featuring maximal allodynia) and then at several time points after drug injection.

Algesiometry. Most behavioral experiments used the von Frey test of mechanical sensitivity (von Frey, 1922). Mice were placed individually in transparent Plexiglas cubicles $(5 \times 8.5 \times 6 \mathrm{~cm})$ placed upon a perforated metal floor and habituated for $2 \mathrm{~h}$ before behavioral testing began. Nylon monofilaments $(\approx 0.015-1.3 \mathrm{~g}$; Touch Test Sensory Evaluator Kit, Fibers 2-9; Stoelting) were firmly applied to the plantar surface of each hindpaw of an inactive mouse until they bowed for $0.5 \mathrm{~s}$. The up-down method of Dixon (Chaplan et al., 1994) was used to estimate 50\% withdrawal thresholds.

Testing of noxious thermal sensitivity occurred using the radiant heat paw-withdrawal test (Hargreaves et al., 1988). Mice were placed individually in transparent Plexiglas cubicles $(5 \times 8.5 \times 6 \mathrm{~cm})$ placed upon a 3/16th-inch-thick glass floor and habituated for $2 \mathrm{~h}$ before behavioral testing. The stimulus was a high-intensity beam (IITC model 336; setting $=3, \approx 45 \mathrm{~W}$ ) from a projector lamp bulb located $6 \mathrm{~cm}$ below the glass floor aimed at the plantar surface of the mid-hindpaw of an inactive mouse. Withdrawal latency of each hindpaw was measured to the nearest $0.1 \mathrm{~s}$. Reported values are means of two successive latency determinations at that time point (before and $3 \mathrm{~d}$ after CFA).

Spontaneous pain was tested using the Mouse Grimace Scale (Langford et al., 2010). Each mouse was placed in an individual chamber $(9 \times$ $5 \times 5 \mathrm{~cm}$ ) having transparent Plexiglas outer walls to allow experimental observation, opaque plastic inner walls that isolated each mouse visually from all others, and a wire mesh floor. Mice were habituated for $30 \mathrm{~min}$ before behavioral testing. Cameras directed at the front and back of the cubicle recorded $30 \mathrm{~min}$ of facial expressions before and $24 \mathrm{~h}$ after CFA injection. This time point was used instead of $3 \mathrm{~d}$ after injection because facial grimacing subsides from $24-48 \mathrm{~h}$ after the stimulus (Matsumiya et al., 2012). One clear facial image was taken for every 3 min interval using Rodent Face Finder Software. The images were scrambled and scored blindly for facial grimacing as described previously (Langford et al., 2010).

Drugs. Minocycline (50 $\mu$ g, i.t.), naloxone (5 $\mu$ g, i.t.), naltrindole ( $5 \mu$ g, i.t.), nor-binaltorphimine ( $5 \mu$ g, i.t.), and LPS ( $1 \mu$ g, i.t.) were purchased from Sigma-Aldrich. $\beta$-Funaltrexamine ( $5 \mu$ g, i.t.) was purchased from Tocris Bioscience. Minocycline and LPS doses were chosen based on previous findings of efficacy (in males) (Sorge et al., 2011, 2015). Opioid antagonist doses were chosen based on previous demonstrations in the literature of successful blockade of opioid-mediated an- 


\section{A CFA Allodynia - Minocycline}
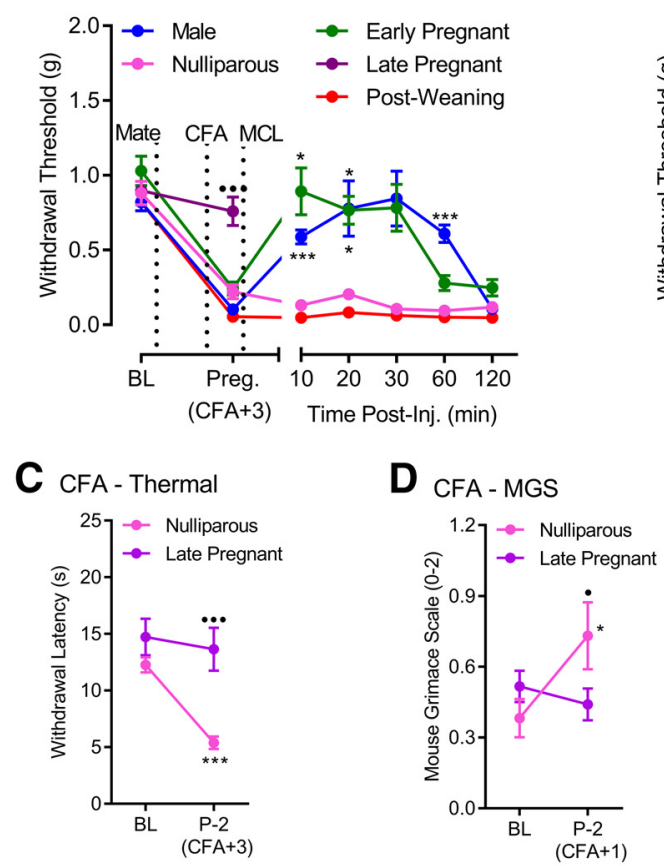

Figure 1. Effect of pregnancy on persistent pain and its sensitivity to reversal by minocycline. $A, B$, Mechanical allodynia produced by $C F A(A)$ and SNI $(\boldsymbol{B})$ is reversed by intrathecal minocycline (MCL) in male and early-pregnant mice ( $14 \pm 2 \mathrm{~d}$ before parturition; $\mathrm{P}-14)$, but not nulliparous or postweaning ( $7 \pm 1 \mathrm{~d}$ postweaning and $28 \mathrm{~d}$ postparturition; P28) female mice. Late-pregnant mice ( $2 \pm 2$ d before parturition; $P-2)$ display no mechanical allodynia. Symbols represent mean \pm SEM ipsilateral hindpaw withdrawal threshold (g) prepregnancy (baseline; BL), $3 \mathrm{~d}$ after CFA (pregnancy/CFA +3), or $7 \mathrm{~d}$ after SNI (pregnancy/SNI +7), and 10 -120 min after injection of $\mathrm{MCL} ; n=7-9$ mice/condition. C, CFA produces thermal hyperalgesia in nulliparous female but not late-pregnant $(\mathrm{P}-2)$ mice. Symbols represent mean \pm SEM ipsilateral hindpaw withdrawal latency (s) prepregnancy (BL) and $3 \mathrm{~d}$ after (FA (CFA +3); $n=8-10$ mice/condition. $\boldsymbol{D}$, (FA produces spontaneous pain in nulliparous female but not late-pregnant $(\mathrm{P}-2)$ mice. Symbols represent mean \pm SEM Mouse Grimace Scale score prepregnancy (BL) and $1 \mathrm{~d}$ after $\mathrm{CFA}$ $($ CFA +1$) ; n=7-8$ mice/condition. In all cases, male and nulliparous female mice were tested with delays between baseline and subsequent testing equivalent to late-pregnant mice. $E$, LPS produces allodynia in male and early-pregnant ( $P-14)$ mice, but not nulliparous and late-pregnant $(\mathrm{P}-2)$ mice. Symbols represent mean \pm SEM bilateral hindpaw withdrawal threshold $(\mathrm{g})$ at baseline (BL) and 1-24h after injection of LPS; $n=6-8$ mice/condition. ${ }^{*} p<0.05,{ }^{* *} p<0.01$, ${ }^{* * *} p<0.001$ compared with (FA +3 (in graph $\boldsymbol{A}$ ), $\mathrm{SNI}+7$ (in graph $\boldsymbol{B}$ ), or $\mathrm{BL}$ (in graphs $\boldsymbol{C}-\boldsymbol{E}$ ). $\bullet_{p}<0.05$ compared to all other groups at the same time point. $\bullet \bullet<0.001$ compared with all other groups at the same time point.

algesia (Qi et al., 1990; Malmberg and Yaksh, 1992; Menendez et al., 1993; Dawson-Basoa and Gintzler, 1996).

Adoptive transfer. Spleens harvested from CD-1 female mice using aseptic technique were placed in sterile, ice-cold RPM1-1640 medium (Sigma-Aldrich) and 10\% FBS (Sigma-Aldrich). Cells were then strained into a single-cell suspension. After centrifugation $(500 \times g$ for $5 \mathrm{~min}$ at $4^{\circ} \mathrm{C}$ ), red blood cells were lysed in ACK lysis buffer (Invitrogen) on ice for 5 min. Cells were diluted with RPMI/FBS buffer and centrifuged as described previously. Cells were counted on a hemocytometer using Trypan blue (Sigma-Aldrich). Cells were centrifuged as above and either suspended in sterile $0.9 \%$ saline, or further separated into $\mathrm{CD} 3{ }^{+}, \mathrm{CD} 4{ }^{+}$, or $\mathrm{CD} 8{ }^{+}$cell populations using a Qiagen cell sorting kit. Unfractionated splenocytes $\left(10^{7}\right.$ cells in $\left.0.5 \mathrm{ml}\right), \mathrm{CD}^{+}\left(5 \times 10^{6}\right.$ cells in $\left.0.5 \mathrm{ml}\right), \mathrm{CD}^{+}$ $\left(4 \times 10^{6}\right.$ cells in $\left.0.5 \mathrm{ml}\right)$, or CD8 ${ }^{+}\left(3 \times 10^{6}\right.$ cells in $\left.0.5 \mathrm{ml}\right)$, were injected intraperitoneally into $\mathrm{nude}$ female mice, which received an intraplantar injection of CFA on the same day. Behavioral testing was performed $72 \mathrm{~h}$ after cell transfer.

Quantitative RT-PCR. Dorsal lumbar (L4-L6) spinal cords and dorsal root ganglia (DRG) were removed in freshly killed mice and total RNA isolated (RNeasy Universal Kit; Qiagen) and reverse transcribed (RT ${ }^{2}$ First Strand Kit; Qiagen). Amplification of Oprm1, Oprd1, and Oprk1 (assay IDs: Mm00445273_ml, Mm01180757_ml, and Mm01230885_m1, respectively; Thermo Fisher Scientific) was performed using Applied Biosystems Quantstudio 3 with TaqMan probes and primers as per the manufacturer's protocol using $n=3$ technical replicates. Relative quan- tification was made following the $\Delta \Delta \mathrm{CT}$ method. Results were averaged and normalized by dividing mean values of the opioid receptor gene by mean values of the housekeeping gene 18S (assay ID: Mm03928990_g1; Thermo Fisher Scientific).

\section{Results}

In all experiments using minocycline or LPS, vehicle control groups were run concurrently; because no significant repeatedmeasures effects of vehicle were obtained in any experiment, these data are omitted for clarity. Also omitted for clarity in most graphs are data obtained on the hindpaw contralateral to CFA or SNI; notable effects on the contralateral paw are referred to in the text below.

\section{Inflammatory and neuropathic allodynia in early-pregnant mice shows male-like microglial dependence} Young adult CD-1 male and female mice (nulliparous, in the first week of pregnancy, in the last week of pregnancy, or 1 week postweaning) were tested for mechanical sensitivity, given an inflammatory (CFA) or neuropathic (SNI) injury, and retested 3 or $7 \mathrm{~d}$ later, respectively (Fig. 1). With the important exception of late-pregnant mice (see below), no differences in the magnitude of mechanical allodynia were observed among groups (CFA condition $\times$ repeated measures, baseline [BL] vs pregnancy: $F_{(3,25)}=0.5$, $p=0.68$; SNI condition $\times$ repeated measures, BL vs pregnancy: $F_{(3,27)}=1.6, p=$ $0.21)$. Immediately after testing on day 3 after CFA or day 7 after SNI, all mice received an intrathecal injection of minocycline (or saline) and were retested at 10-120 min after injection. Minocycline was effective in reversing allodynia produced by CFA (Fig. 1A) and SNI (Fig. 1B) in male but not nulliparous female mice, as we have demonstrated previously (Sorge et al., 2015). However, female mice in the early stages of pregnancy were also minocycline sensitive, whereas previously pregnant but not currently lactating mice (i.e., postweaning) were not (CFA, condition $\times$ repeated measures, pregnancy-120 min: $F_{(15,125)}=5.7, p<0.001$; SNI condition $\times$ repeated measures, pregnancy-120 $\mathrm{min}: F_{(15,135)}=8.6, p<$ $0.001)$.

\section{Late-pregnant mice have no evidence of pain after injury}

Mice within $4 \mathrm{~d}$ of parturition were observed to have no mechanical allodynia after either CFA (repeated-measures BL vs pregnancy: $F_{(1,6)}=2.1, p=0.20$; Fig. $1 A$ ) or SNI (repeated-measures BL vs pregnancy: $F_{(1,7)}=2.7, p=0.15$; Fig. $1 B$ ). Late-pregnant mice (and no other group) treated with CFA or undergoing SNI displayed strong trends toward frank analgesia on the contralateral hindpaw as well $\left(\mathrm{CFA}: F_{(1,6)}=3.7, p=0.10\right.$; SNI: $F_{(1,7)}=3.1$, $p=0.12$ ).

To establish the generalizability of this apparent pregnancyrelated analgesia, we compared nulliparous female mice with late-pregnant mice on two other symptom modalities $3 \mathrm{~d}$ after 
CFA injection. We observed that latepregnant mice did not display significant thermal hypersensitivity (condition $\times$ repeated measures: $F_{(1,16)}=13.6, p=0.002$; Fig. $1 C$ ) or spontaneous pain measured via facial grimacing (condition $\times$ repeated measures: $F_{(1,13)}=9.8, p=0.008$; Fig. 1D).

Because we demonstrated previously that male but not female mice use TLR $4 \mathrm{~s}$ to process pain in the spinal cord (Sorge et al., 2011), we tested mice for mechanical allodynia produced by intrathecal injection of the TLR4 agonist LPS. LPS produced allodynia for 6-24 $\mathrm{h}$ in male and early-pregnant mice, but not nulliparous or late-pregnant mice (condition $\times$ repeated measures: $F_{(15,130)}=5.5, p<0.001$; Fig. 1E).

\section{Hormonal and opioid dependence of pregnancy analgesia}

These observations are obviously reminiscent of the work of Gintzler (1980), who showed that thresholds to behavioral responding to electric shock in rats increased during pregnancy. His work demonstrated, among other things, that pregnancy analgesia could be mimicked by hormone-stimulated pregnancy (DawsonBasoa and Gintlzer, 1996) and that the phenomenon was mediated by endogenous opioids (Gintzler, 1980). To establish whether our observations represented a similar process, we performed studies on naive female mice.

First, four groups of mice were ovariectomized (OVX) and then implanted subcutaneously with an osmotic minipump releasing vehicle, estradiol, progesterone, or both hormones together at concentrations observed previously to produce hormone-stimulated pregnancy (HSP) and analgesia in rats (Dawson-Basoa and Gintzler, 1993). Eleven days later, all mice received CFA, such that post-CFA testing occurred on day 14 after hormone treatment. Neither OVX or pump implantation per se significantly affected mechanical sensitivity in any group (hormone $\times$ repeated measures BL to day $+11: F_{(6,40)}=2.1, p=$ $0.08)$. As shown in Figure $2 A$, CFA allodynia occurred in all groups except the HSP group (hormone $\times$ repeated measures day +11 to day $\left.+14: F_{(3,20)}=4.0, p=0.02\right)$. Similar findings were obtained for SNI. In this experiment, mice were given the nerve injury first, then OVX, and then implanted with a pump. Again, the OVX had no effect on allodynia in any group (hormone $\times$ repeated measures + SNI to + OVX: $F_{(3,17)}=0.2$, $p=0.86)$. As shown in Figure $2 B$, only HSP reversed allodynia (hormone $\times$ repeated measures + OVX to day $+14: F_{(3,17)}=8.5$, $p=0.001)$.

To establish whether spinal cord (or DRG) opioid receptors were mediating the analgesia, we attempted to reinstate mechanical allodynia in pregnant mice with intrathecal naloxone. In the CFA experiment, mice were mated and in late pregnancy injected with CFA. Three days later, immediately after confirming that no allodynia was present, mice were injected with naloxone or saline and retested at 15-120 min after injection. As shown in Figure 2C, naloxone reinstated the "hiding" allodynia for at least $60 \mathrm{~min}$

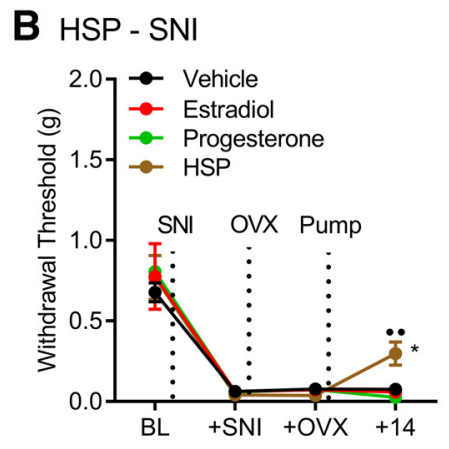

D Naloxone - SNI

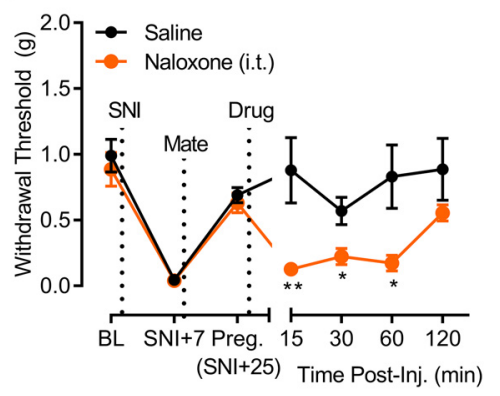

(SNI+25) Time Post-Inj. ( $\mathrm{min})$

Figure 2. Hormone and opioid dependence of pregnancy analgesia. $\boldsymbol{A}, \boldsymbol{B}$, Simultaneous adminstration of estradiol and progesterone (HSP) produces abolition of mechanical allodynia from CFA $(\boldsymbol{A})$ and SNI $(\boldsymbol{B})$. Symbols represent mean \pm SEM ipsilatera 至 with $+11(\operatorname{graph} \boldsymbol{A}),+0 \mathrm{VX}(\operatorname{graph} \boldsymbol{B}), \mathrm{CFA}+3(\operatorname{graph} \boldsymbol{C})$, or SNI $+25(\operatorname{graph} \boldsymbol{D}) . \boldsymbol{\bullet}_{p}<0.01$ compared to all other groups at the same time point. $\bullet_{p}<0.001$ compared with all other groups at the same time point.

$\left(\right.$ drug $\times$ repeated measures pregnancy-120 min: $F_{(4,64)}=2.8$, $p=0.03)$. In the SNI experiment, mice were given the nerve injury first, and $7 \mathrm{~d}$ later (after allodynia was confirmed) were mated. In late pregnancy, immediately after confirming that allodynia was no longer present, mice were injected with naloxone or saline. As shown in Figure 2D, naloxone also reinstated SNIinduced allodynia for at least $60 \mathrm{~min}$ (drug $\times$ repeated measures pregnancy-120 min: $\left.F_{(4,40)}=3.2, p=0.02\right)$.

\section{T-cell dependence of pregnancy analgesia}

To establish more precisely the time course of pregnancy analgesia, we subjected female CD-1 and T-cell-deficient nude mice to SNI or sham surgery, confirmed the presence of ipsilateral allodynia on day 7 after surgery, and immediately thereafter mated all mice. Mice were retested for withdrawal thresholds at various time points during pregnancy and after parturition. As shown in Figure $3 A$, mice displayed a progressive loss of ipsilateral SNI allodynia throughout pregnancy (repeated-measures SNI day +7 to $\left.\mathrm{P}-2: F_{(6,42)}=8.3, p<0.001\right)$. Sham-operated mice also displayed a statistically significant frank analgesia developing through pregnancy $\left(F_{(6,36)}=2.5, p=0.04\right)$, as did both SNI- and sham-operated mice on the hindpaws contralateral to the injury $\left(F_{(6,42)}=4.2, p=0.002\right.$ and $F_{(6,36)}=3.0, p=0.02$, respectively $)$. At $4 \mathrm{~d}$ before parturition, withdrawal thresholds had returned statistically to their presurgery baseline values and, by $3 \mathrm{~d}$ after parturition (regardless of whether the pups were removed from the dams), mechanical allodynia was fully reinstated. This progressive loss of mechanical allodynia through pregnancy was entirely absent in T-cell-deficient nude mice given SNI (repeated 


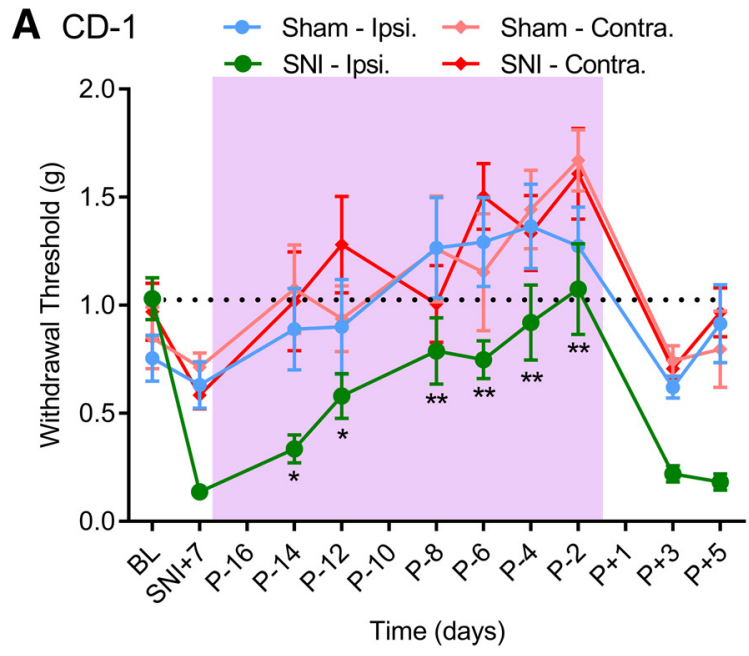

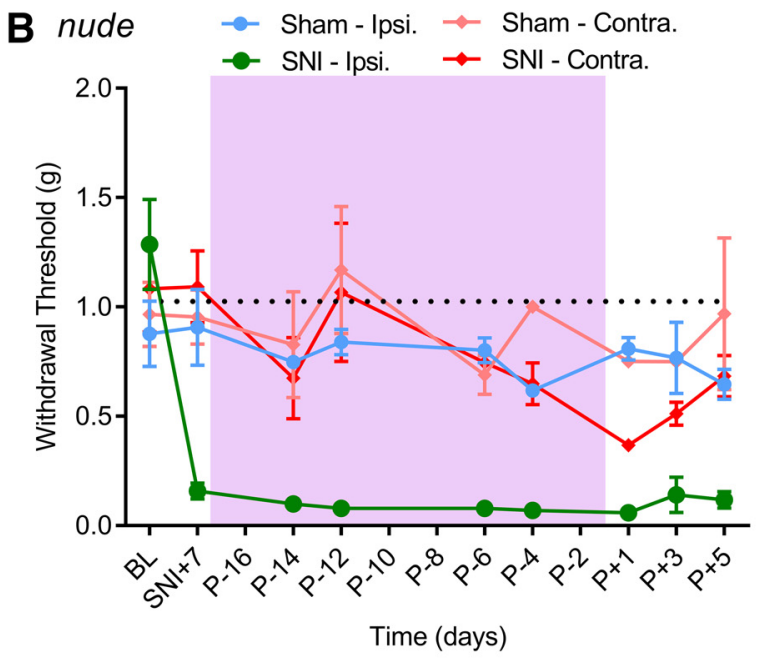

\section{E nude + Adoptive Transfer}

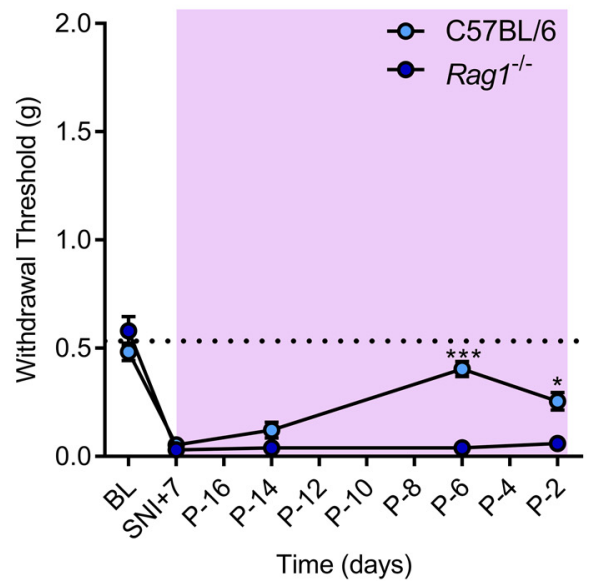

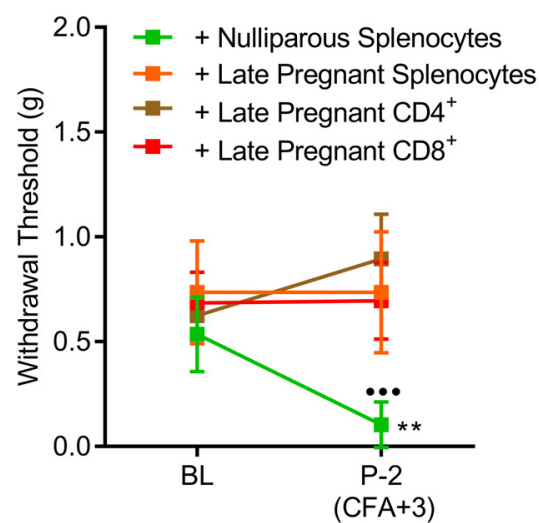

Figure 3. T-cell dependence of pregnancy analgesia. $\boldsymbol{A}, \boldsymbol{B}$, Progressive attenuation of $S \mathrm{Nl}$-induced mechanical allodynia during pregnancy, and reinstatement after parturition, in $(D-1(\boldsymbol{A})$ but not nude (B) mice. Symbols represent mean \pm SEM ipsilateral (Ipsi.) and contralateral (Contra.) hindpaw withdrawal threshold (g) at baseline (BL), at day 7 after SNI or sham surgery (SNI + 7), and at various time points before $(\mathrm{P}-x)$ and after $(\mathrm{P}+x)$ parturition; $n=6-8 \mathrm{mice} / \mathrm{genotype} / \mathrm{surgery}$. Purple shading indicates duration of pregnancy. C, Attenuation of SNI-induced mechanical

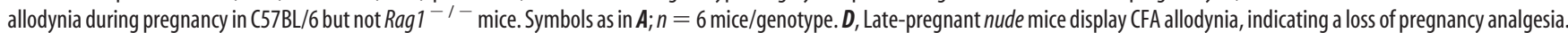
Symbols represent mean \pm SEM ipsilateral hindpaw withdrawal threshold (g) at prepregnancy (BL) and on day 3 after CFA at $P-2$ (CFA +3 ); $n=7-10$ mice/genotype/condition. $E$, Adoptive transfer of splenocytes or isolated $\mathrm{CD} 4^{+}$or $\mathrm{CD} 8^{+} \mathrm{T}$ cells from pregnant $\mathrm{CD}-1$ mice into late-pregnant nude mice blocks CFA allodynia, indicating a restoration of pregnancy analgesia. Symbols as in $\boldsymbol{D} ; n=5-8$ mice/condition. ${ }^{*} p<0.05,{ }^{* *} p<0.01,{ }^{* * *} p<0.001$ compared with SNI +7 (graphs $\boldsymbol{A}-\boldsymbol{C}$ ) or BL (graphs $\boldsymbol{D}$ and $\boldsymbol{E}$ ). In graph $\boldsymbol{A}$, asterisks in conditions other than SNI-Ipsi. are omitted for clarity. ${ }^{\bullet \bullet} p<0.001$ compared with all other groups at the same time point.

measures SNI day +7 to $\mathrm{P}-4: F_{(4,26)}=0.1, p=0.98$; Fig. $\left.3 B\right)$. Analgesia in sham-operated mice and on the contralateral hindpaws was also entirely absent in nude mice (all $p>0.40$; Fig. $3 B$ ).

To confirm that the lack of pregnancy analgesia in nude female mice was indeed due to T-cell deficiency, we first replicated the study described above using Rag1-null mutant $\left(\operatorname{Rag}^{-1-}\right)$ mice and their wild-type controls, C57BL/6. C57BL/6 mice displayed a significant reduction of allodynia in late pregnancy (although not a complete reversal like CD-1). Rag $1^{-1-}$ mice, like nude mice, showed no alteration whatsoever of mechanical allodynia through pregnancy (genotype $\times$ repeated measures SNI day +7 to P-2: $F_{(3,24)}=24.2, p<0.001$; Fig. $3 C$ ).

A lack of pregnancy analgesia in nude mice after CFA was also observed (genotype $X$ pregnancy state $X$ repeated measures: $F_{(1,21)}=6.2, p=0.02$; Fig. $\left.3 D\right)$. To further confirm the involvement of $\mathrm{T}$ cells in the production of this analgesia, we used a new cohort of late-pregnant nude mice given CFA and adoptively transferred splenocytes from nulliparous CD-1 mice or splenocytes, isolated $\mathrm{CD}^{+}{ }^{+} \mathrm{T}$ cells, or isolated $\mathrm{CD} 8{ }^{+} \mathrm{T}$ cells from late- pregnant CD-1 mice. As shown in Figure 3E, adoptive transfer of all cell populations from late-pregnant CD-1 mice were able to restore pregnancy analgesia (i.e., abolish the mechanical allodynia) in nude mice (adoptive transfer condition $\times$ repeated measures: $\left.F_{(3,24)}=4.1, p=0.02\right)$.

\section{$\delta$-Opioid receptor mediation of pregnancy analgesia}

Because pregnancy analgesia has been shown previously to be opioid receptor dependent (Dawson-Basoa and Gintzler, 1996; Dawson-Basoa and Gintzler, 1997, 1998) and because we also observed reinstatement of CFA and SNI allodynia after intrathecal naloxone administration, we endeavored to define the opioid receptor subtype specificity of the phenomenon. We first performed quantitative RT-PCR of the classical opioid receptor genes, Oprm1 $(\mu)$, Oprd1 $(\delta)$, and Oprk1 $(\kappa)$, in the two potential sites of action of intrathecal naloxone: the DRG and the spinal cord. CD-1 nulliparous and late-pregnant mice were compared with nude mice of the same status; naive animals were used because the pregnancy analgesia can be seen in uninjured mice. As 
A DRG

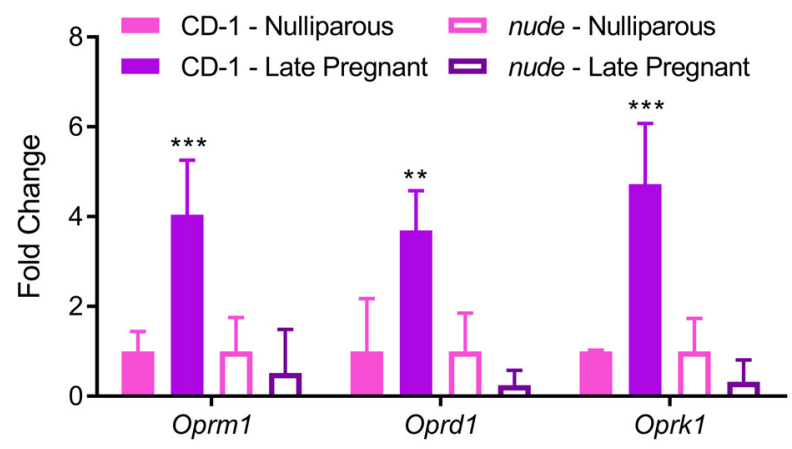

B Spinal Cord

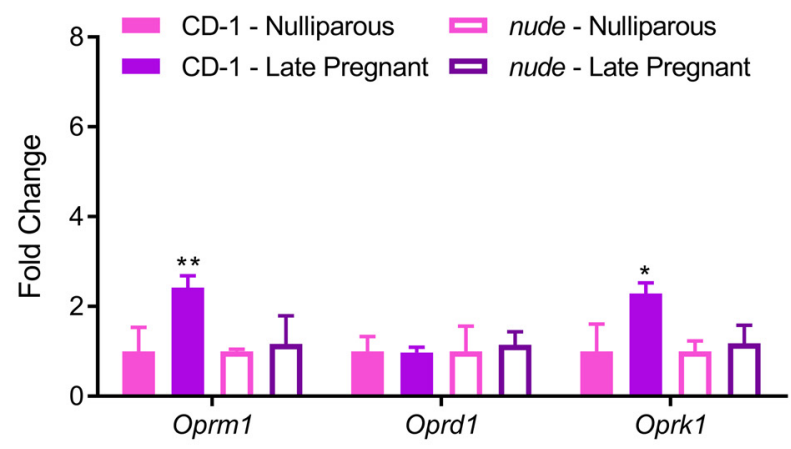

\section{Subtype-Specific Antagonists}

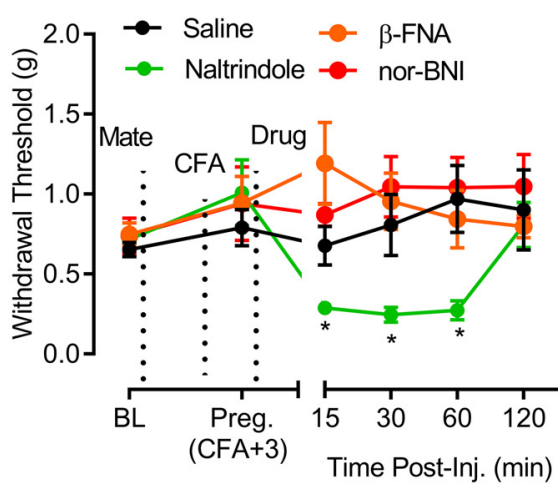

D Oprd1 $1^{-1-}$

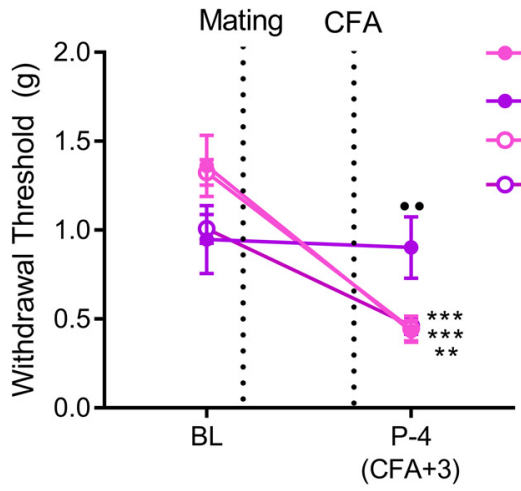

Figure 4. $\delta$-0pioid receptor dependence of pregnancy analgesia. $\boldsymbol{A}, \boldsymbol{B}$, Relative expression of the Oprm1, Oprd1, and Oprk1 genes in the DRG $(\boldsymbol{A})$ and spinal cord ( $\boldsymbol{B})$ of nulliparous and late pregnant CD-1 and nude mice. Error bars indicate mean \pm SEM relative expression normalized to nulliparous $C D-1$ mice. $C$, Intrathecal injection of naltrindole, but not $\beta$-funaltrexamine ( $\beta$-FNA) or nor-binaltorphimine (nor-BNI), reinstates "hidden" (FA allodynia in late-pregnant mice. Symbols represent mean \pm SEM ipsilateral hindpaw withdrawal threshold (g) prepregnancy (BL), on day 3 after (FA at $P-2$ (pregnancy/CFA +3 ), and $15-120$ min after injection of drug; $n=6-9$ mice/drug. $D$, Pregnancy analgesia is absent in late-pregnant Oprd $1^{-1-}$ mice. Symbols represent mean \pm SEM ipsilateral hindpaw withdrawal threshold $(\mathrm{g})$ prepregnancy $(\mathrm{BL})$, at $\mathrm{P}-7, \mathrm{and} 3 \mathrm{~d}$ after $\mathrm{CFA}(\mathrm{P}-4 / \mathrm{CFA}+3) ; n=5-8$ mice/genotype/condition. ${ }^{*} p<0.05,{ }^{* *} p<0.01,{ }^{* *} p<0.001$ compared with nulliparous (D-1 (graphs $\boldsymbol{A}$ and $\boldsymbol{B}$ ), (FA+3 (graph $\boldsymbol{C}$ ), or BL (graph $\boldsymbol{D}$ ). $\bullet \bullet \bullet<0.01$ compared with all other groups at the same time point.

shown in Figure $4 A$, pregnancy produced an $\approx 4$-fold upregulation of all three opioid receptor genes in the DRG compared with nulliparous mice (Oprm1: $t_{(8)}=5.3, p<0.001 ;$ Oprd1: $t_{(8)}=4.1$, $p=0.003$; Oprk1: $\left.t_{(8)}=6.2, p<0.001\right)$; no hint of similar increases were observed in nude mice (all $p>0.7$ ). A smaller but still statistically significant increase was seen in the spinal cord for $\operatorname{Oprm1}\left(t_{(5)}=4.7, p=0.005\right)$ and Oprk1 $\left(t_{(5)}=3.9, p=0.01\right)$, but not Oprd1 $\left(t_{(5)}=0.2, p=0.88\right.$ ) (Fig. $4 B$ ). Because both opioid receptors in the DRG and the spinal cord are capable of producing analgesia, these gene expression findings permit the potential role of all three receptor subtypes. To determine which of them are actually relevant to pregnancy analgesia, we intrathecally injected the subtype-specific antagonists $\beta$-funaltrexamine $(\mu)$, naltrindole $(\delta)$, and nor-binaltorphimine $(\kappa)$. As seen in Figure $4 C$, only the $\delta$-opioid receptor antagonist naltrindole was capable of reinstating the "hiding" allodynia in a manner similar to naloxone $\left(\right.$ drug $X$ repeated measures pregnancy-120 min: $F_{(12,108)}=3.1$, $p=0.001)$. To confirm the relevance of the $\delta$-opioid receptor, we tested nulliparous and late-pregnant Oprd1-null mutant $\left(\mathrm{Oprd1} 1^{-I^{-}}\right)$ mice compared with wild-type (C57BL/6) controls for CFA allodynia. Late-pregnant Oprd1 ${ }^{-/-}$mice displayed unaltered allodynia compared with nulliparous mutants (genotype $\times$ pregnancy status $\times$ repeated measures: $\left.F_{(1,18)}=6.9, p=0.02\right)$, indicating the lack of pregnancy analgesia (Fig. 4D).

\section{Discussion}

\section{Microglial-dependent and -independent pain processing}

The present study documents two separate phenomena related to the neuroimmune processing of chronic pain in pregnant female mice. First, we observed that female mice in the early stages of pregnancy display-like male mice, but unlike nulliparous or postweaning female mice-minocycline-reversible mechanical allodynia. The insensitivity to minocycline reversal of allodynia we interpret, as we have previously (Sorge et al., 2015), as a "switching" over from a microglial-dependent to a parallel, nonmicroglial-dependent pain-processing mechanism in the spinal cord. That females do not use spinal cord microglia to process allodynia is supported by the insensitivity of female mice (and rats; J. Mapplebeck, R. Dalgamo, O. Moriarty, S. Beggs, Y. Tu, C. Kwok, J. Mogil, T. Trang, and M. Salter, unpublished data) to blockade of allodynia via not only intrathecal minocycline, but also spinal administration of the following: (1) fluorocitrate, (2) propentofylline, (3) the P2X inhibitor TNP-ATP, (4) the p38 MAPK inhibitor SB203580, (5) the NGF/BDNF inhibitor Y1036, (6) the BDNF-sequestering fusion protein TrkB-Fc, (7) the caspase-6 inhibitor ZVEID7; or (8) the microglial toxin Mac-1saporin (Sorge et al., 2015; Berta et al., 2016; Taves et al., 2016). Also in support of this contention are the male-specific pain phenotypes of $C \times 3 c r 1^{\text {CreER }}-B d n f$ (Sorge et al., 2015; but see Peng 
et al., 2016) and caspase-6-null mutant (Berta et al., 2016) mice. We believe that this parallel "female-specific" mechanism involves $\mathrm{T}$ cells, based on the following: (1) the sensitivity of even female T-cell-deficient mouse strains (nude and Rag1 ${ }^{-1-}$ ) to allodynia reversal by microglial inhibitors; (2) effective reinstatement of microglial inhibitor insensitivity by adoptive transfer of splenocytes; and (3) female-specific reversal of allodynia by pioglitazone, which blocks T-cell-expressed peroxisome proliferator activated receptor-gamma (Sorge et al., 2015). Experiments are ongoing in our laboratory to provide additional evidence of female-specific T-cell involvement in pain processing and these experiments are now including early-pregnant mice. We note that the adaptive immune environement is greatly affected by sex hormones; whereas males have a more dominant Th2 immune population in their circulating $\mathrm{CD} 4{ }^{+}$cells, females have a higher Th1-dominant immune environment (Whitacre et al., 1999). Because our ongoing studies have suggested that it is indeed CD ${ }^{+}$ $\mathrm{T}$ cells that are responsible for producing hypersensitivity in female mice, known decreases in the Th1/Th2 ratio during pregnancy (Whitacre et al., 1999) might explain the "switching" of early-pregnant mice to an alternate pain processing pathway. Studies in human arthritics have found that an increase in Th2 cytokines during pregnancy positively correlates with improvement of disease activity (Ostensen, 1992).

\section{T-cell dependence of $\boldsymbol{\delta}$-opioid-mediated pregnancy analgesia} Second, and the main focus of this study, we observed that female mice in the late stages of pregnancy do not display any evidence of mechanical allodynia after inflammation, nerve damage, or LPS; thermal hyperalgesia after inflammation; or spontaneous inflammatory pain. Although pregnancy analgesia has been demonstrated in both rats (Gintzler, 1980; Iwasaki et al., 1991) and mice (Jayaram et al., 1995; Jayaram et al., 1997), we are aware of only one prior preclinical demonstration that the phenomenon can be seen in the context of persistent pain. Using the chronic constriction injury (CCI) assay of neuropathic pain, Onodera et al. (2017) very recently reported the loss of mechanical allodynia at $21 \mathrm{~d}$ of pregnancy. They also observed that CCI-induced increases in tumor necrosis factor- $\alpha$, the immediate-early gene Fos, activated astrocytes (GFAP), and activated microglia (Iba-1) were absent in pregnant CCI mice (Onodera et al., 2017). However, our finding's of (if not always statistically significant) changes in nociceptive sensitivity on the hindpaw contralateral to the injury and in sham-operated animals suggest that this phenomenon does not represent a specific anti-hypersensitivity process so much as a frank pregnancy-related analgesia. That is, it appears that the reduced mechanical allodynia observed in the late stages of pregnancy simply represents the sum of the allodynia caused by the injury and the analgesia associated with pregnancy itself.

Therefore, we believe the phenomenon under study herein appears to be the same one discovered in 1980 by Alan Gintzler. Indeed, like Gintzler and colleagues (Dawson-Basoa and Gintzler, 1993), we observe that pregnancy analgesia can be produced in nonpregnant, ovariectomized mice by simulating pregnancylike gonadal hormone conditions; only simultaneous pump administration of estrogen and progesterone were found to block allodynia. Furthermore, we observe that intrathecal injection of the broad-spectrum opioid receptor antagonist naloxone to latepregnant mice not displaying mechanical allodynia resulted in the temporary unmasking of that allodynia; that is, produced a temporary blockade of the pregnancy analgesia that was counteracting it. Unlike Gintzler, we show here that pregnancy analgesia in the mouse is dependent on $\mathrm{T}$ cells and (uniquely) $\delta$-opioid receptors. Pregnancy produced a robust upregulation of all three genes (Oprm1, Oprd1, and Oprk1) coding for the classical opioid receptor subtypes - $\mu, \delta$, and $\kappa$, respectively - in the DRG, and a smaller upregulation of the Oprm1 and Oprk1 genes in the spinal cord. Activation of any or all of these receptors might be expected to produce analgesia. In the rat, Gintzler and colleagues demonstrated the importance of a synergistic interaction between $\delta$-opioid and $\kappa$-opioid receptors (Dawson-Basoa and Gintzler, $1998)$; selective antagonism of the $\mu$-opioid receptor did not affect pregnancy analgesia (Dawson-Basoa and Gintzler, 1996). The implications of this apparent species difference need to be explored in future work, as does the status in the mouse of a parallel mechanism of pregnancy analgesia in the rat involving $\alpha_{2}$-noradrenergic activity (Liu and Gintzler, 1999). It is of interest that the only extant work on pregnancy analgesia in the mouse revealed the involvement of enkephalins (Jayaram et al., 1995; Jayaram et al., 1997), which are of course the endogenous ligands of the $\delta$-opioid receptor.

This effect of pregnancy on opioid gene expression appeared to be T-cell dependent because none of these increases appeared in pregnant nude mice. Opioid (and especially $\delta$-opioid) receptor regulation of T-cell proliferation and functioning is well known; activated $\mathrm{T}$ cells release enkephalins that can modulate $\mathrm{T}$ cells via autocrine and paracrine binding to $\delta$-opioid receptors (Sharp, 2006). Antigen-primed CD $4^{+} \mathrm{T}$ cells are well known to release endogenous opioids in the periphery and thereby cause analgesia (Cabot et al., 1997; Verma-Gandhu et al., 2006; Boué et al., 2011). After injury, antigen-presenting cells migrate to the lesion site, followed by T cells, although the exact mechanism of this recruitment is not well understood (Moalem et al., 2004). It is known that injury can activate T cells (Hanschen et al., 2011; Liu et al., 2012), suggesting that the $T$ cells in our experiments may have been primed by the inflammatory or nerve injuries. Experiments aimed at determining the exact mechanism by which $\mathrm{T}$ cells (primed or otherwise) affect opioid gene expression are ongoing. $\mathrm{CD} 4+\mathrm{Th} 2$ cells are known to release anti-inflammatory cytokines such as IL-10 and TGF- $\beta$, which themselves can inhibit pain (Echeverry et al., 2009; Jankovic et al., 2010). Interestingly, null mutants of the BMP and activin membrane bound inhibitor (BAMBI) gene, which is known to be a negative regular of TGF- $\beta$, show increased $\mu$-and $\delta$-opioid receptor expression in the dorsal horn of the spinal cord after SNI (Lantero et al., 2014).

During pregnancy, the maternal immune system undergoes dramatic changes; this includes a robust phenotypic shift of the T-cell population to produce fewer Th1 cytokines and more Th2 cytokines (Reinhard et al., 1998). This shift has been used to explain maternal protection from autoimmunity during pregnancy (Adams Waldorf and Nelson, 2008; Munoz-Suano et al., 2012). More generally, we note the rapidly increasing evidence of a role of $\mathrm{T}$ cells in chronic pain processing and modulation (Costigan et al., 2009; Li et al., 2013; Draleau et al., 2014; Liu et al., 2014; Zhang et al., 2014; Austin et al., 2015; Liu et al., 2015; Luchting et al., 2015; Sorge et al., 2015; Vicuña et al., 2015; Duffy et al., 2016; Krukowski et al., 2016; Massart et al., 2016; Shubayev et al., 2016; Baddack-Werncke et al., 2017). The current observations reinforce the notion that the adaptive immune system is an underappreciated source of pain modulation and one that might be exploited clinically.

\section{References}

Adams Waldorf KM, Nelson JL (2008) Autoimmune disease during pregnancy and the microchimerism legacy of pregnancy. Immunol Invest 37:631-644. CrossRef Medline 
Austin PJ, Berglund AM, Siu S, Fiore NT, Gerke-Duncan MB, Ollerenshaw SL, Leigh SJ, Kunjan PA, Kang JW, Keay KA (2015) Evidence for a distinct neuro-immune signature in rats that develop behavioural disability after nerve injury. J Neuroinflammation 12:96. CrossRef Medline

Baddack-Werncke U, Busch-Dienstfertig M, González-Rodriguez S, Maddila SC, Grobe J, Lipp M, Stein C, Müller G (2017) Cytotoxic T cells modulate inflammation and endogenous opioid analgesia in chronic arthritis. J Neuroinflammation 14:30. CrossRef Medline

Beggs S, Salter MW (2010) Microglia-neuronal signalling in neuropathic pain hypersensitivity 2.0. Curr Opin Neurobiol 20:474-480. CrossRef Medline

Berta T, Qadri YJ, Chen G, Ji RR (2016) Microglial signaling in chronic pain with a special focus on caspase 6, p38 MAP kinase, and sex dependence. J Dent Res 95:1124-1131. CrossRef Medline

Block HS, Biller J (2014) Neurology of pregnancy. Handb Clin Neurol 121: 1595-1622. CrossRef Medline

Boué J, Blanpied C, Brousset P, Vergnolle N, Dietrich G (2011) Endogenous opioid-mediated analgesia is dependent on adaptive $\mathrm{T}$ cell response in mice. J Immunol 186:5078-5084. CrossRef Medline

Cabot PJ, Carter L, Gaiddon C, Zhang Q, Schäfer M, Loeffler JP, Stein C (1997) Immune cell-derived $\beta$-endorphin: production, release, and control of inflammatory pain in rats. J Clin Invest 100:142-148. CrossRef Medline

Casagrande D, Gugala Z, Clark SM, Lindsey RW (2015) Low back pain and pelvic girdle pain in pregnancy. J Am Acad Orthop Surg 23:539-549. CrossRef Medline

Chaplan SR, Bach FW, Pogrel JW, Chung JM, Yaksh TL (1994) Quantitative assessment of tactile allodynia evoked by unilateral ligation of the fifth and sixth lumbar nerves in the rat. J Neurosci Methods 53:55-63. CrossRef Medline

Cogan R, Spinnato JA (1986) Pain and discomfort thresholds in late pregnancy. Pain 27:63-68. CrossRef Medline

Costigan M, Moss A, Latremoliere A, Johnston C, Verma-Gandhu M, Herbert TA, Barrett L, Brenner GJ, Vardeh D, Woolf CJ, Fitzgerald M (2009) $\mathrm{T}$-cell infiltration and signaling in the adult dorsal spinal cord is a major contributor to neuropathic pain-like hypersensitivity. J Neurosci 29: 14415-14422. CrossRef Medline

Dawson-Basoa M, Gintzler AR (1997) Involvement of spinal cord $\delta$ opiate receptors in the antinociception of gestation and its hormonal simulation. Brain Res 757:37-42. CrossRef Medline

Dawson-Basoa M, Gintzler AR (1998) Gestational and ovarian sex steroid antinociception: synergy between spinal $\kappa$ and $\delta$ opioid systems. Brain Res 794:61-67. CrossRef Medline

Dawson-Basoa MB, Gintzler AR (1993) $17-\beta$-Estradiol and progesterone modulate an intrinsic opioid analgesic system. Brain Res 601:241-245. CrossRef Medline

Dawson-Basoa ME, Gintzler AR (1996) Estrogen and progesterone activate spinal kappa-opiate receptor analgesic mechanisms. Pain 64:169-177. CrossRef Medline

Decosterd I, Woolf CJ (2000) Spared nerve injury: an animal model of persistent peripheral neuropathic pain. Pain 87:149-158. CrossRef Medline

Draleau KS, Maddula S, Slaiby A, Nutile-McMenemy N, De Leo JA, Cao L (2014) Phenotypic identification of spinal cord-infiltrating CD4+ T lymphocytes in a murine model of neuropathic pain. J Pain Relief Suppl 3:003. Medline

Duffy SS, Perera CJ, Makker PG, Lees JG, Carrive P, Moalem-Taylor G (2016) Peripheral and central neuroinflammatory changes and pain behaviors in an animal model of multiple sclerosis. Front Immunol 7:369. Medline

Dunbar AH, Price DD, Newton RA (1988) An assessment of pain responses to thermal stimuli during stages of pregnancy. Pain 35:265-269. CrossRef Medline

Echeverry S, Shi XQ, Haw A, Liu H, Zhang ZW, Zhang J (2009) Transforming growth factor- $\beta 1$ impairs neuropathic pain through pleiotropic effects. Mol Pain 5:16. Medline

Gintzler AR (1980) Endorphin-mediated increases in pain threshold during pregnancy. Science 210:193-195. CrossRef Medline

Gintzler AR, Liu NJ (2001) The maternal spinal cord: biochemical and physiological correlates of steroid-activated antinociceptive processes. Prog Brain Res 133:83-97. CrossRef Medline

Goolkasian P, Rimer BA (1984) Pain reactions in pregnant women. Pain 20:87-95. CrossRef Medline
Grace PM, Hutchinson MR, Maier SF, Watkins LR (2014) Pathological pain and the neuroimmune interface. Nat Rev Immunol 14:217-231. CrossRef Medline

Hanschen M, Tajima G, O’Leary F, Ikeda K, Lederer JA (2011) Injury induces early activation of $\mathrm{T}$ cell receptor signaling pathways in CD4+ regulatory T cells. Shock 35:252-257. CrossRef Medline

Hargreaves K, Dubner R, Brown F, Flores C, Joris J (1988) A new and sensitive method for measuring thermal nociception in cutaneous hyperalgesia. Pain 32:77-88. CrossRef Medline

Hylden JL, Wilcox GL (1980) Intrathecal morphine in mice: a new technique. Eur J Pharmacol 67:313-316. CrossRef Medline

Iwasaki H, Collins JG, Saito Y, Kerman-Hinds A (1991) Naloxone-sensitive, pregnancy-induced changes in behavioral responses to colorectal distention: pregnancy-induced analgesia to visceral stimulation. Anesthesiology 74:927-933. CrossRef Medline

Jankovic D, Kugler DG, Sher A (2010) IL-10 production by CD4 ${ }^{+}$effector T cells: a mechanism for self-regulation. Mucosal Immunol 3:239-246. CrossRef Medline

Jayaram A, Singh P, Carp H (1995) SCH 32615, an enkephalinase inhibitor, enhances pregnancy-induced analgesia in mice. Anesth Analg 80:944948. Medline

Jayaram A, Singh P, Noreuil T, Fournié-Zaluski M-C, Carp HM (1997) RB 101 , a purported pro drug inhibitor of enkephalin metabolism, is antinociceptive in pregnant mice. Anesth Analg 84:355-358. Medline

Ji RR, Chamessian A, Zhang YQ (2016) Pain regulation by non-neuronal cells and inflammation. Science 354:572-577. CrossRef Medline

Kimmelman J, Mogil JS, Dirnagl U (2014) To improve translation, distinguish exploratory and confirmatory preclinical research. PLoS Biol 12: e1001863. CrossRef Medline

Krukowski K, Eijkelkamp N, Laumet G, Hack CE, Li Y, Dougherty PM, Heijnen CJ, Kavelaars A (2016) CD8 + T cells and endogenous IL-10 are required for resolution of chemotherapy-induced neuropathic pain. J Neurosci 36:11074-11083. CrossRef Medline

Langford DJ, Bailey AL, Chanda ML, Clarke SE, Drummond TE, Echols S, Glick S, Ingrao J, Klassen-Ross T, Lacroix-Fralish ML, Matsumiya L, Sorge RE, Sotocinal SG, Tabaka JM, Wong D, van den Maagdenberg AM, Ferrari MD, Craig KD, Mogil JS (2010) Coding of facial expressions of pain in the laboratory mouse. Nat Methods 7:447-449. CrossRef Medline

Lantero A, Tramullas M, Pílar-Cuellar F, Valdizán E, Santillán R, Roques BP, Hurlé MA (2014) TGF- $\beta$ and opioid receptor signaling crosstalk results in improvement of endogenous and exogenous opioid analgesia under pathological pain conditions. J Neurosci 34:5385-5395. CrossRef Medline

LeResche L, Sherman JJ, Huggins K, Saunders K, Mancl LA, Lentz G, Dworkin SF (2005) Musculoskeletal orofacial pain and other signs and symptoms of temporomandibular disorders during pregnancy: a prospective study. J Orofac Pain 19:193-201. Medline

Li J, Wei GH, Huang H, Lan YP, Liu B, Liu H, Zhang W, Zuo YX (2013) Nerve injury-related autoimmunity activation leads to chronic inflammation and chronic neuropathic pain. Anesthesiology 118:416429. CrossRef Medline

Liu H, Shiryaev SA, Chernov AV, Kim Y, Shubayev I, Remacle AG, Baranovskaya S, Golubkov VS, Strongin AY, Shubayev VI (2012) Immunodominant fragments of myelin basic protein initiate $\mathrm{T}$ cell-dependent pain. J Neuroinflammation 9:119. CrossRef Medline

Liu H, Dolkas J, Hoang K, Angert M, Chernov AV, Remacle AG, Shiryaev SA, Strongin AY, Nishihara T, Shubayev VI (2015) The alternatively spliced fibronectin CS1 isoform regulates IL-17A levels and mechanical allodynia after peripheral nerve injury. J Neuroinflammation 12:158. CrossRef Medline

Liu NJ, Gintzler AR (1999) Gestational and ovarian sex steroid antinociception: relevance of uterine afferent and spinal $\alpha_{2}$-noradrenergic activity. Pain 83:359-368. CrossRef Medline

Liu XJ, Zhang Y, Liu T, Xu ZZ, Park CK, Berta T, Jiang D, Ji RR (2014) Nociceptive neurons regulate innate and adaptive immunity and neuropathic pain through MyD88 adapter. Cell Res 24:1374-1377. CrossRef Medline

Luchting B, Rachinger-Adam B, Heyn J, Hinske LC, Kreth S, Azad SC (2015) Anti-inflammatory T-cell shift in neuropathic pain. J Neuroinflammation 12:12. CrossRef Medline

Malmberg AB, Yaksh TL (1992) Isobolographic and dose-response analyses of the interaction between intrathecal mu and delta agonists: effects of 
naltrindole and its benzofuran analog (NTB). J Pharmacol Exp Ther 263: 264-275. Medline

Massart R, Dymov S, Millecamps M, Suderman M, Gregoire S, Koenigs K, Alvarado S, Tajerian M, Stone LS, Szyf M (2016) Overlapping signatures of chronic pain in the DNA methylation landscape of prefrontal cortex and peripheral T cells. Sci Rep 6:19615. CrossRef Medline

Matsumiya LC, Sorge RE, Sotocinal SG, Tabaka JM, Wieskopf JS, Zaloum A, King OD, Mogil JS (2012) Using the Mouse Grimace Scale to reevaluate the efficacy of postoperative analgesics in laboratory mice. J Am Assoc Lab Anim Sci 51:42-49. Medline

McMahon SB, La Russa F, Bennett DL (2015) Crosstalk between the nociceptive and immune systems in host defence and disease. Nat Rev Neurosci 16:389-402. CrossRef Medline

Melhado EM, Maciel JA Jr, Guerreiro CA (2007) Headache during gestation: evaluation of 1101 women. Can J Neurol Sci 34:187-192. CrossRef Medline

Menendez L, Andres-Trelles F, Hidalgo A, Baamonde A (1993) Involvement of spinal $\kappa$ opioid receptors in a type of footshock induced analgesia in mice. Brain Res 611:264-271. CrossRef Medline

Moalem G, Xu K, Yu L (2004) T lymphocytes play a role in neuropathic pain following peripheral nerve injury in rats. Neuroscience 129:767-777. CrossRef Medline

Mogil JS, Ritchie J, Sotocinal SG, Smith SB, Croteau S, Levitin DJ, Naumova AK (2006) Screening for pain phenotypes: analysis of three congenic mouse strains on a battery of nine nociceptive assays. Pain 126 24-34.

Munoz-Suano A, Kallikourdis M, Sarris M, Betz AG (2012) Regulatory T cells protect from autoimmune arthritis during pregnancy. J Autoimmun 38:J103-J108. CrossRef Medline

Onodera Y, Kanao-Kanda M, Kanda H, Sasakawa T, Iwasaki H, Kunisawa T (2017) Pregnancy suppresses neuropathic pain induced by chronic constriction injury in rats through the inhibition of TNF- $\alpha$. J Pain Res 10: 567-574. CrossRef Medline

Ostensen M (1992) The effect of pregnancy on ankylosing spondylitis, psoriatic arthritis, and juvenile rheumatoid arthritis. Am J Reprod Immunol 28:235-237. CrossRef Medline

Ostensen M, Villiger PM (2007) The remission of rheumatoid arthritis during pregnancy. Semin Immunopathol 29:185-191. CrossRef Medline

Peng J, Gu N, Zhou L, B Eyo U, Murugan M, Gan WB, Wu LJ (2016) Microglia and monocytes synergistically promote the transition from acute to chronic pain after nerve injury. Nat Commun 7:12029. CrossRef Medline

Qi JA, Heyman JS, Sheldon RJ, Koslo RJ, Porreca F (1990) Mu antagonist and kappa agonist properties of $\beta$-funaltrexamine ( $\beta$-FNA) in vivo: longlasting spinal analgesia in mice. J Pharmacol Exp Ther 252:1006-1011. Medline

Reinhard G, Noll A, Schlebusch H, Mallmann P, Ruecker AV (1998) Shifts in the TH1/TH2 balance during human pregnancy correlate with apoptotic changes. Biochem Biophys Res Commun 245:933-938. CrossRef Medline
Rust M, Keller M, Gassler M, Zieglgansberger W (1985) Endorphinergic mechanisms of specific adaptation to pain during pregnancy. Abst XI World Congress of Gynecology and Obstetrics 452.

Saito S, Nakashima A, Shima T, Ito M (2010) Th1/Th2/Th17 and regulatory T-cell paradigm in pregnancy. Am J Reprod Immunol 63:601-610. CrossRef Medline

Scotland RS, Stables MJ, Madalli S, Watson P, Gilroy DW (2011) Sex differences in resident immune cell phenotype underlie more efficient acute inflammatory responses in female mice. Blood 118:5918-5927. CrossRef Medline

Sharp BM (2006) Multiple opioid receptors on immune cells modulate intracellular signaling. Brain Behav Immun 20:9-14. Medline

Shields SD, Eckert WA 3rd, Basbaum AI (2003) Spared nerve injury model of neuropathic pain in the mouse: a behavioral and anatomic analysis. J Pain 4:465-470. CrossRef Medline

Shubayev VI, Strongin AY, Yaksh TL (2016) Role of myelin auto-antigens in pain: a female connection. Neural Regen Res 11:890-891. CrossRef Medline

Sorge RE, et al. (2015) Different immune cells mediate mechanical pain hypersensitivity in male and female mice. Nat Neurosci 18:1081-1083. CrossRef Medline

Sorge RE, LaCroix-Fralish ML, Tuttle AH, Sotocinal SG, Austin JS, Ritchie J, Chanda ML, Graham AC, Topham L, Beggs S, Salter MW, Mogil JS (2011) Spinal cord Toll-like receptor 4 mediates inflammatory and neuropathic hypersensitivity in male but not female mice. J Neurosci 31: 15450-15454. CrossRef Medline

Taves S, Berta T, Liu DL, Gan S, Chen G, Kim YH, Van de Ven T, Laufer S, Ji RR (2016) Spinal inhibition of p38 MAP kinase reduces inflammatory and neuropathic pain in male but not female mice: sex-dependent microglial signaling in the spinal cord. Brain Behav Immun 55:70-81. CrossRef Medline

Verma-Gandhu M, Bercik P, Motomura Y, Verdu EF, Khan WI, Blennerhassett PA, Wang L, El-Sharkawy RT, Collins SM (2006) CD4+ T-cell modulation of visceral nociception in mice. Gastroenterology 130:17211728. CrossRef Medline

Vicuña L, Strochlic DE, Latremoliere A, Bali KK, Simonetti M, Husainie D, Prokosch S, Riva P, Griffin RS, Njoo C, Gehrig S, Mall MA, Arnold B, Devor M, Woolf CJ, Liberles SD, Costigan M, Kuner R (2015) The serine protease inhibitor SerpinA3N attenuates neuropathic pain by inhibiting T cell-derived leukocyte elastase. Nat Med 21:518-523. CrossRef Medline

von Frey M (1922) Verspatete schmerzempfindungen. Z Gesamte Neurol Psychiat 79:324-333. CrossRef

Whitacre CC, Reingold SC, O'Looney PA (1999) A gender gap in autoimmunity. Science 283:1277-1278. CrossRef Medline

Zhang X, Wu Z, Hayashi Y, Okada R, Nakanishi H (2014) Peripheral role of cathepsin $S$ in Th1 cell-dependent transition of nerve injury-induced acute pain to a chronic pain state. J Neurosci 34:3013-3022. CrossRef Medline 